\title{
BARRIERS AND WAYS OF CREATIVTY DEVELOPMENT IN MUSIC EDUCATION
}

Significance of creativity and its pedagogical and psychological attributes, difference in its interpretation, situation in the world. An outline of authors and their works in Slovakia or in the Czech Republic, barriers of creativity, competence, attributes and abilities, personality of the music teacher. Methods and forms of creative music education, an application of various games, especially musical ones, role as well as dramatic plays. Project work. Creativity and new multimedia technologies. The profile of an unsuccessful music teacher. Models of creative exercises, practical experience and their application.

\section{Introduction}

Creativity education and its development is very important for our life. Without it the cultural and aesthetic values would have not been created in the past. Creativity relates to self-realization of man, his instinctive spontaneity, curiosity, experimentation, thinking as well as imagination, intuition, desire for something new, unknown; hope, search for the meaning of life, the feeling of freedom when expressing his thoughts and emotional experiences. And not only with the aim to satisfy his own needs. It is also an interaction of a subject with an object and synergetic effect of interpersonal communication. It means to do and change something in our environment, community, society and the whole human civilisation as well. Harvard psychologist Robert White, a representative of "egopsychology", uses the term competence. "Ego is motivated by biological instincts as well as the outside world and most of all by the need of exploration, learning, coping with the environment." [In: 1]. The effectiveness of motivation relates to a tendency to put effort with the aim to influence the environment. When this effort is successful, the individual feels competent. Such a source of motives leads the man to the development of his own potential and to coping with his environment.

From the pedagogical-psychological point of view newness and originality belong to the basic attributes of creativity. The openness of milieu, the liberty and respect for others' opinions, the riches of thoughts and discussion, support and empathy, trust in relatioships, playfulness and humour, not exaggerating critique and evaluation, creation of space for inventiveness, development of ideas and solutions, impulsion of curiosity and motivation for cognition, the combination of team work and individual responsibility can be included among procreative phenomena. The most valuable part of human education is not any longer the knowledge of facts (within the meaning of existing viewpoint) but the ability to work with information - the pupil should learn to obtain new information by analysis and synthesis of pieces of knowledge, create hypotheses and verify them, process the information and formulate a piece of knowledge. The ability of his/her own judgement, critical and creative thinking and acts, refreshing and enriching his knowledge during the whole active period of his/her life are much more necessary.

\section{Creative abilities, traits and states of personality}

Nowadays it is difficult to characterise creative phenomena scientifically and quantitatively. However, we can use qualitative criteria and analytical methods of creative expressions of musical activities. They are "fed" by following creative abilities, traits and states of personality: 1. Flexibility, the ability to take advantage of acquired musical experience, to adjust this musical experience to new situations and to overcome old techniques of solution. 2. Fluency, the ability of an individual to react to musical impulses with a great number of variations and alternatives. There is also a place for intuition and musical insight. 3 . Elaboration, the ability to develop and process creative musical thinking into the most detailed form. The elaboration also opens opportunities for playing with musical thoughts, for their transforming on the basis of already acquired musical experience and knowledge. The starter is also musical imagination, various emotional reactions, various visual perceptions, synesthesias etc. 4 . Originality is usually considered to be the most important expression of creativity. It is creation of something entirely new and unique. 5 . Analysis, the ability which enables to perceive musical parts meaningfully and to find relations among them. 6. Synthesis-integration, connects constructional parts into musically logical unit. 7. Sensitivity, the ability which enables the individual to perceive and react to the structure and dynamics of musical impulses. 8. Concentration of attention, a psychological state which is connected with an increased inner activation of attention. Inspiration is an escalating psychological state. It appears as a strong excitement, enormous rush of energy and maximal concentration. 9. Restructuring, this ability relates to the revision of a final form of musical product. These abilities are not isolated in creative process [2]. They unite in creative experienc-

\footnotetext{
* Peter Krbata

Faculty of Science, University of Žilina, Slovakia, E-mail: peter.krbata@fpv.uniza.sk
} 
ing and thinking. They are determined by bio-psycho-social dispositions, endowments, faculty, talent and a product of biodromal development. They originate and develop in the process of socialization. Creativity in music has also other dimensions. Understandably, this is the question of a favoured theoretical approach in the field of psychology of creativity. What is the state and what trends are there in this field of research?

\section{Present theories of creativity}

At present a wide range of various theories of creativity coexist side by side more or less harmoniously. They are represented by cognitivist, personalistic and interactionist approaches. Their founders are, for example: J. P. Guilford, McKinnon, F. Barron, D. M. Harington, E. P. Torrance, C. Rogers, S. G. Isaaksen, D. J. Treffinger etc. They have many followers: R. B. Butcher, T Yarnell, T. Z. Tardiff, R. J. Sternberg, H. Gardner, E. Gordon, D. E. Smith, D. W. Tegano, K. H. Lennon, M. Thibeaulth, M. Waterman, T. M. Amabile, W. Roscher etc. [3, 4]. In the Czech Republic the best-known authors are: J. Hlavsa, J. Viewegh, M. Jůzl, J. Kulka, I. Pýchová, J. Herden, P. Žák, H. Váňová etc. In Slovakia they are E. Komárik, I. Šuleková, T. Kováč, M. Zelina, M. Zelinová, E. Szobiová, M. Krupa, P. Krbata, E. Baranová, B. Felix, J. Hatrík, E. Langsteinová, T. Pirníková, Z. Sláviková, M. Krušinská, J. Zeleiová, M. Bohonyová and from the younger generation P. Špilák, K. Macková etc. The complicatedness of relations among single components of creativity and their unique interlinkings are objects of research activities of the research workers of the Department of Creativity Psychology at the Institute of Experimental Psychology of the Slovak Academy of Sciences in Bratislava. M. Jurčová and D. Kusá are researchers responsible for the mentioned grant projects.

\section{Our own contribution}

This contribution about understanding creativity is based on various research and practical pedagogical experience from the Academy of Music and Dramatic Arts in Bratislava, the Faculty of Humanities and the Academy of Arts in Banská Bystrica. Creativity seminars are run at the Faculty of Science of the University of Žilina under my supervision [5,6]. In every person there is a need to realise himself/herself creatively. For example, it is the music teacher who contributes creatively to the education of children, students, adults or of older generation studying at universities of the third age /our case in the University of Žilina - Man-art major/. In the individual interaction the music teacher speaks; develops children's musical faculty and talent; he teaches them to sing, to play the musical instruments, to understand the world of music; he accepts children's feelings; he uses praise; he utilizes children's ideas, images, fantasy, imagination; he forms their abilities and skills; he helps to solve children's personal problems, to overcome their laziness, tiredness, stage fright, to boost their selfconfidence, to discover other values of life /the role of a motherfather/, to navigate them in their further maturation and headway /the role of a manager/ etc. Although the music teacher teaches predominantly music, $\mathrm{s} / \mathrm{he}$ is a paragon of a pedagogue, musician and a human for the children.

We can learn about the personality of the music teacher, the high or low quality of his/her educational activities according to the results of his/her work. However, this general statement is not sufficient. These results show manifold individual psychological differences: pedagogical talent, personal qualities, skills, knowledge, experience in singing, playing the instrument; character traits and also the knowledge of using effective teaching methods. The music teacher can achieve the same goals in various ways. There are several phases in exploring the personality from the standpoint of the personality psychology. The 1st phase was represented by the psychophilosophy of the personality research. It was cultivated for all the centuries and it flourished at the end of the 19th century. It was based on constitutional, attitudinal and character traits /Hippocrates, Carus, Schiller, Dilthey, Janet, Kraepelin/ but without experimental verification. The 2nd phase already brought experimental investigation. New typologies were researched by: Ach, Ehrenstein, Erich and Walter Jaensch, Kretschmer, Krueger, Sander, Phahler but also by representatives of psychoanalysis - Freud, Jung, Adler, Horney, Fromm etc. These typologies were based on measurement of personality by means of apparatus, however, an appropriate statistical method for investigation of the relations among features of personality and for integration of numerous theories was missing. Later the Anglo-American school took the lead in the investigation of personality. This $3 \mathrm{rd}$ phase had the distinction of statistical and empirical orientation /Eysenck, Cattel, representatives of humanistic-cognitive theories - Maslow, Rogers, Lewin, Kelly etc./. The 4th phase was the continuation of the former one but it was enriched by investigation of the causes of behaviour and experiencing, inner and outer factors which changed this or that feature of personality /Rogers, Allport, White etc./. The humanistic approach deals with the man who possesses potential for healthy and creative growth and self-realisation /unlike behaviorism - which as it is known - overestimated upbringing, training/. It is represented by the logotherapeutic school of V.E. Frankl and his student Lukas and Bern's theory of role plays. At present the project Millennium uses almost all these humanistic approaches while organising learning environment. They should lead to the development of children's personality, their initiative, creativity, self-confidence, independence and responsibility. And the music teacher? Concerning pedagogical performance except from the formal one which $\mathrm{s} / \mathrm{he}$ has to follow according to the curriculum, s/he can significantly "open a creative gate" for children's manifold activities in an informal way, mainly by means of learning through experience.

The better the music teacher succeeds in finding the right way of teaching and motivating pupils and students, the greater will be his motivation to seek and create something new. Many times it is motivation which determines the style of teaching, evokes atmosphere of creativity and interest in learning. For instance, the content area itself, the problem which the pupil has to solve and the teacher's appraisal can motivate. There is space for realisation of music therapy and various games. These games are based on the interaction and dramatic action with a real or imaginary partner. 
The project work has a broad potential for the development of creativity. The use of multimedia /various musical software for music composition, editing, notation, reproduction, karaoke systems, multimedial encyclopedias of music, dictionaries, music games for children of various age, visual presentations in power point or flash software, dataprojections, etc./ in the area of music is also very important. [7, 8, 9, 10].

\section{Barriers and ways of creativity development}

Hesitation, prejudices, lack of self-confidence and self-respect, fear that "I will make a mistake", the undue control of behaviour, weak sense for a game, feeling that "I can socially disgrace myself", insufficient motivation and inability to decide to do further step are the obstacles for the development of creativity. Bad material and spatial conditions, insufficient teaching aids and instrumental equipment, an unsuitable timetable and problematical management of school are obstacles, too. To a large extent, the relationship of the pupil to the music education depends on the teacher's personality, on his/her professional preparation and on his/her ability to motivate students. My survey from 2004, in which 65 respondents (music teachers of primary art schools, primary schools, conservatories, academies and universities) participated, deals with what kind of personality the music teacher should embody. According to the results of this survey the majority of respondents stated that the music teacher should not be a conservative type without any ability to adapt to new conditions, man who does not accept new trends and alternatives in the process of teaching music and music theory. It is a fault if $\mathrm{s} /$ he is affected by complexes. The unsuccessful teacher does not know himself/herself, his/her abilities and limits. $\mathrm{S} / \mathrm{he}$ is not a strong character and e is not able to defend his/her principles and opinions. S/he does not understand meaning of music. From the psychological viewpoint, further contraindication is if $\mathrm{s} / \mathrm{he}$ is mentally unstable, nervous, impulsive, ironical, selfish, impatient, intolerant and arrogant. The reader can find furher results in [5].

It is not good if the teacher demands from his/her pupil to play the musical instrument as a "machine". If his/her pupil cannot technically manage a certain part /if it is difficult for him/her/, $\mathrm{s} /$ he can emotionally express this problem. Abilities of the teacher to help his/her pupil through a piece of advice (in case of his/her personal problems, in overcoming anxiety, stage fright and tiredness) also belong to unwritten rules. They include the ability to diagnose pupil's real mental and physical state. A good teacher knows that a pupil is often uncritical in his/her self-evaluation, therefore $\mathrm{s} /$ he gives him/her a chance to evaluate performances of other pupils. The music teacher communicates with parents, too. $\mathrm{S} /$ he must be educated in theoretical disciplines and must search for something new. $\mathrm{S} /$ he does not work only in class but also broadens his/her horizons in other spheres of life. An ideal paragon of the teacher is such a teacher who is endowed by voice, intonational, rhytmical, instrumental, musical-historical, musical-theoretical and form-analytical skills. $\mathrm{S} /$ he is of a strong personality with charisma of pedagogue, musician and human.

\section{Creativity seminars}

To begin with I would like to explain principles of expression and stimulation of creativity to my students. They are: 1 . Voluntariness and courage. Not every student takes part in exercises actively. It is important for him/her to be open to simulated situations and to take them as a game. The condition is that the student should be enthusiastic, original and tolerant towards "crazy" or unique ideas. I try to set him/her free from possible stage fright and anxiety for example, by means of relaxation techniques. 2 . Security and discretion. Nothing can be misused! There is atmosphere without suspense, emotional threat and fear of anything unusual, new and original. It is acceptable if anybody does not feel well and does not want to participate actively. 3. Playfulness, spontaneity and humour. Any manifestations of imagination and fantasy are tolerated. Laugh facilitates formation of original ideas and thoughts. 4. Joy and freedom of speech. The process of musical and dramatical games and role-plays is sometimes more important than the outcome. 5. Praise and encouragement. The less creative solutions are accepted with appreciation and praise. 6 . Trust and cooperation. Initiating and supporting creative group atmosphere. Positive expectations. 7. Exercise evaluation. Motivational importance of mutual evaluation. Everybody needs admiration and appreciation.

Another part of this phase is recording and categorising students' ideas about contents of seminars. It is very important to identify interesting creative individuals. Many of them have rich experience and abilities in various fields of art /dance, music, acting, prose, poetry, fine arts, film, video, photography etc./ and new electronic, information and communication technologies /computers, creation of web sites, graphic design etc./. Others devote themselves to sports, various hobbies of collecting and are experienced in the area of education, communication, management and organising a number of interesting actions. University teachers quite often do not know about these interests and experience.

Various games, for example expositions of chosen pieces of music /for instance, a composition by G. Scelsi, an electroacoustic composition Jupiter by Norwegian composer J. Persen etc./ are approached in other creativity seminars. They are about reflexion at various levels - from physiological to philosophical reflexion. I also provide the students a witty picture to which they react with their original observations. I use many modifications of brainstorming, relaxation methods, assertive and empathic techniques, musicotherapeutic sessions, jam-session productions, imaginary games with a ball and other objects. Students prepare short acting scenes /creation of a script, a text, choreography, costumes etc./. We practise various acting etudes /students change rhythm or tempo of dramatic action in these etudes/. Students suggest dance activities of various styles and musical kinds. A lot of attention is paid to creative nonverbal expressive manifestations /manual communication, pantomime, proxemics etc./, creative expression of fine arts in connection with music. Students train verbal abilities /lecture on a drawn theme, recitation of a text with various emotional expression, creation of metaphors, interviews - a presenter, an editor versus certain typologies and social categories of people/. 
Students create statues or sculptural groups according to the model artworks of French sculptor A. Rodin. While doing project work, students who are divided into groups prepare plans for establishing music agencies, various societies, associations or movements /reasons for establishing; characterisation of their activity, mission; objectives etc./. The last exercise is a short theatre scene "Spacemen on the planet X" or a collective dance production. The final meeting is an opportunity for evaluation of our meetings. During this meeting the best videorecordings and photographs are projected. The experience acquired in this way deepens every student's awareness of his/her own "self", which may have impact on the students_successfulness both during their studies and in practical situations.

Translation: Mgr. Veronika Trpišová

\section{References}

[1] FONTANA, D.: Psychology in School Training, Praha, Portál, 1997

[2] KRBAŤA, P.: The Psychology of Music (not only) for Musicians, Book Monography, Prešov, Matúš Music, 1994

[3] DACEY, J. S., LENNON, K. H.: Creativity, Praha, Grada, 2000

[4] KIRST, W., DIEKMEYER, U.: Creativity Training, Praha, Portál, 1998

[5] KRBAT̄A, P.: The Psychological Aspects of Pedagogical Performance, Banská Bystrica, Muses in School, 2/2004

[6] KRBAT̄A, P.: Mediamatics and Music - Connections of the Third Digital Culture, Collection "Music-pedagogical Interpretations 6.", Nitra, University of Constantine the Philosopher, 2001

[7] FORRÓ, D.: Computers and Music, Praha, Grada, 1993

[8] GAŠPAR, I.: Information and Communication Technologies in Music Education, Teacher's Profession and Contemporary Society: $12^{\text {th }}$ Conference of Czech Association of Pedagogical Research, $1^{\text {st }}$ edition, Ústí nad Labem, University of Jan Evangelist Purkyně, 2004

[9] KRBAŤA, P.: Creation of Music and Computer Graphics, Learning Texts for the University of the Third Age, University of Žilina, 2003

[10] TAUFER, J.: Attendance Internet Page: http:<//www.volny.cz/jiri.taufer $>$. 